\title{
DEVELOPING ESL/EFL LEARNERS’ PUBLIC SPEAKING SKILLS THROUGH PECHA KUCHA PRESENTATIONS
}

\author{
Romualdo A. Mabuan \\ Lyceum of the Philippines University \\ E-mail: romualdo.mabuan@lpu.edu.ph
}

APA Citation: Mabuan, R. A. (2017). Developing ESL/EFL learners' public speaking skills through Pecha Kucha presentations. English Review: Journal of English Education, 6(1), 110. DOI: $10.25134 /$ erjee.v6i1.765.

Published: 01-12-2017

\begin{abstract}
In the $21^{\text {st }}$ century workplace, there has been an increasing demand for graduates to possess communicative competence particularly in speaking. Anchored on the $21^{\text {st }}$ Century Learning Framework (Partnership for $21^{\text {st }}$ Century Skills or P21, 2006) and the TPACK Framework (Koehler \& Mishra, 2009), this study reports findings on the pedagogical viability of utilizing Pecha Kucha 20x20 Presentations in developing students' competence and confidence while presenting in the language classroom. Research participants include 43 English as Second Language (ESL) learners taking Speech Communication classes in a private university in Manila, the Philippines during the second semester of the academic year 2016-2017. Research data from students' reflections, interviews, survey, and focus group discussion (FGD) suggest that despite some format and technological limitations, delivering Pecha Kucha presentations may help students develop their English speaking and oral presentation skills, build their confidence in speaking before an audience, and practice their English macro skills such as listening and reading. In the light of these findings, pedagogical implications are provided for ESL (English as a second language) and EFL (English as a foreign language) teachers, communication educators, and researchers.
\end{abstract}

Keywords: Teaching speaking, Pecha Kucha Presentations, ESL public speaking, TPACK

\section{INTRODUCTION}

One of the significant concerns in developing communicative competence among ESL/EFL learners is their reluctance to speak in the classroom - a pedagogical challenge that English language teachers face in the context of $21^{\text {st }}$ Century Learning, which espouses the development of 4Cs among students to prepare them for success in life and in their profession: critical thinking skills, creativity, collaboration, and communication (Partnership for $21^{\text {st }}$ Century Skills, 2006). Of these skills, many people put premium to communication, because in most cases, a person's ability and value to the organization is judged not so much on what he can do, but on how well he can explain what he does (Souter, 2007).

However, no matter how much teachers work hard to develop their students' English public speaking skills, speech anxiety remains to be a hurdle to many students. Anxiety is defined as an unpleasant feeling similar to fear (Lader, 1975), or "the subjective feeling of tension, apprehension, nervousness, and worry..." (Horwitz, Horwitz, \& Cope, 1986, p. 125). In the context of public speaking, anxiety is defined as "those situations when an individual reports that he or she is afraid to deliver a speech" (Ayers \& Hopf, 1993, p.4) as cited in (Ciarrocca, 2015). McCroskey (1984) refers to this as Communication Apprehension (CA), an area of inquiry extensively researched since mid-1930s but remains to be relevant up to present. In the current curriculum where active oral language practices only take place for about $5 \%$ of daily class time in the typical English classroom (Milner, Milner, \& Mitchell, 2012), there is a need to provide more opportunities to the students to engage in meaningful and effective oral communication activities and to help them develop competence and confidence in public speaking.

Presentations play a large role in the business world today; they are the daily rituals 
of the corporate life (Souter, 2007). Despite the ubiquity and constant hum of computermediated communication (CMC), people continue to spend more and more of their lives engaging in face-to-face communication, interacting with others, giving and receiving information, sharing and selling ideas, and laying the groundwork for important decisions. Presentations are how people do business in corporate world, and in the context of Outcomes-Based Education (Spady, 1994), communication teachers face the challenge of reflecting this reality in their language classrooms so that their students develop effective communication skills and graduate fully-equipped, competent, and confident to face the world of work.

Practicing public speaking in the classroom, whether individually or in small groups, can help students develop their confidence in preparing and delivering oral presentations (King, 2002) as cited in (Nguyen, 2015), help them plan, prepare, and perform better for their future professionrelated tasks (Nguyen, 2015), and overcome their public speaking anxiety (Liao, 2014). Practicing oral presentations can also develop students' listening, speaking, reading, writing, critical thinking, and higher order research skills (Iberri-Shea, 2009; Manchey, 1986) as cited in (Ciarrocca, 2015). This is supported by Al-Issa and Al-Qubtan (2010) as cited in (Nguyen, 2015) who claimed that aside from building students' confidence and decisionmaking skills in topic selection, performing oral presentations is an integrative approach that helps develop students' English macro skills as they practice writing notes and scripts for their slides, read texts related to their presentation, speak to audience, and listen for questions and feedback cues from the audience. Finally, Munby (2011) as cited in (Nguyen, 2015) argued that performing oral presentations can develop self-directed learning and empowerment among students, help them identify their individual capacities, and enhance their presentation skills through peer feedback mechanisms.

Developed by British architects Astrid Klein and Mark Dytham in Tokyo, Japan in February 2003, Pecha Kucha (pronounced pe- chuk-cha, more commonly heard as pe-chaku-cha) is a Japenese term for chit-chat or informal and friendly talk. It is a fast-paced presentation that uses Microsoft Office PowerPoint slides in a $20 \times 20$ format, which corresponds to 20 pictures or images shown for 20 seconds each, for a total presentation time of 6 minutes and 40 seconds (www.pechakucha.org/faq, 2016). Upon timing setup in the Advance Slide section of the PowerPoint, the images transit automatically and the presenter talks along with the slides, carefully matching his words with the images, but also focusing on the topic and the audience.

The Pecha Kucha presentation format has been popularly adopted around the world. It has become a global phenomenon: there are Pecha Kucha training and workshops, Pecha Kucha nights in over 900 cities in the world (www.pechakucha.org/global, 2016), and almost 19,000 Pecha Kucha videos on YouTube (Smith, 2013). It has been adopted by universities, industries, and professional conference organizers, has been regularly voted as the most popular session and a novel way of presenting (Downing \& Martindale, 2011; Hass, 2011) as cited in (Tomsett \& Trott, 2014), and has received positive reviews: 'excellent, succinct, informative'; 'great format, really well done' (Smith, 2013). The format is regarded as an "amazing cure for death by PowerPoint" and is recommended for use in business presentations based on how it "forces speakers to refine, and refine, and refine again" (Berkun, 2010) as cited in (Christianson \& Payne, 2011). Pecha Kucha presentations have also been popularly used in presenting class work and projects in academia (Foyle \& Childress, 2015) as cited in (Nguyen, 2015) and are now commonly integrated in the classroom across a range of disciplines.

Pecha Kucha presentations have been explored and investigated in different contexts. In her Postgraduate Certificate in Higher Education class at a university in United Kingdom, Smith (2013) decided to liven up her class sessions by asking her students to create and deliver Pecha Kuchas on class topics such as learning theories and theorists. Post-presentation evaluation revealed that 
despite concerns on long preparation, strict structure, and challenging delivery, students described Pecha Kuchas as an 'interesting approach to gain an overview of complex topics' and a 'good way of identifying the essentials'. Smith concluded that Pecha Kuchas could be a powerful means of developing students' synthesis, summary, and time-keeping skills as well as adding excitement to presentations.

In an American university, Soto-Caban, Selvi, and Avila-Medina (2011) as cited in (Nguyen, 2015) adopted the original Pecha Kucha $20 \times 20$ format in asking their engineering students who had experience using PowerPoint presentations but had no experience using Pecha Kucha in presenting their research project results. Findings suggested that compared to other traditional presentation formats in the classroom, utilizing Pecha Kuchas developed their students' communication skills more effectively. This is supported by the work of Chritianson and Payne (2011) with their engineering students, which showed the effectiveness of Pecha Kuchas in enhancing students' presentation skills and creating engaging presentations compared to traditional presentations with a time limit.

Other studies also compared the effectiveness of Pecha Kuchas compared to PowerPoints. Klentzin et al. (2010) claimed that in a lecture context, Pecha Kucha proved to be a better instruction method. This corroborated with the findings in the study carried out by Beyer (2011) and Beyer, Gaze, and Lazicki (2012) which suggested that Pecha Kuchas were favored by the students, had quality similar to or better than PowerPoints, were "more appealing", and were an effective tool in developing students' presentation and image design skills.

In EFL contexts, Pecha Kuchas have also been studied. Ryan (2012) as cited in (Nguyen, 2015) claimed that Pecha Kucha presentations can help improve students' pronunciation and intonation, pointing out that Pecha Kucha's fixed and controlled timing and the English language's characteristic of being stress-timed may help students "achieve natural sounding connected speech" (p.25).
Nguyen (2015), in an EFL reading class of engineering majors in Japan, used Pecha Kuchas in asking students to create presentations based on topics from the class readings. Results revealed that despite some negative feedback on presentation pacing and personal shyness among students, Pecha Kuchas were considered beneficial in improving students' reading comprehension, speaking, and oral presentation skills.

The foregoing foreign studies underpin benefits of using Pecha Kuchas in various academic contexts, but provide no specific findings on the use of Pecha Kuchas in local ESL settings in the Philippines particularly in oral communication classes. Pecha Kucha nights are held in different venues in urban Manila and other parts of the country, yet there is dearth of literature discussing Pecha Kucha's applicability and viability in pedagogical contexts. Drawing from the $21^{\text {st }}$ Century Learning Framework (Partnership for $21^{\text {st }}$ Century Learning, 2006) and the Technological Pedagogical and Content Knowledge or TPACK Framework (Koehler \& Mishra, 2009), this study aims to fill that research gap, as it explores and examines students' views and attitudes towards the use of Pecha Kuchas in an ESL speech class in a private university setting in the Philippines.

Conceptualizing, designing and implementing the current study as guided by the principles of the foregoing paradigms require careful planning and decision making. The Technological Pedagogical and Content Knowledge (TPACK) Framework developed by Koehler and Mishra (2009) informs this study on how to successfully integrate Pecha Kuchas into the Filipino ESL speech class context. TPACK attempts to capture some of the essential qualities of knowledge required by teachers for technology integration in their teaching. It shows the complex interplay and interconnections of the three primary forms of knowledge - Content (C), Pedagogy (P), and Technology - that results in the following intersections: Pedagogical Content Knowledge (PCK), Technological Content Knowledge (TCK), Technological Pedagogical Knowledge (TPK), and Technological Pedagogical Content Knowledge (TPCK). 
TPACK guides this study in developing sensitivity to the dynamic and transactional relationship among all three components and in flexibly navigating the spaces defined by these key elements in the utilization of technology in a speech class.

With the pedagogical aim of developing and enhancing students' communication skills particularly their English oral presentations skills, this ICT-embedded study on the utilization of Pecha Kucha presentations in the Speech Communication class intends to answer the following questions:

1. How do students view the use of Pecha Kuchas in the speech communication class?

2. What are the students' attitudes towards the use of Pecha Kuchas in delivering their oral presentations in the class?

\section{METHOD}

This study utilized a qualitative research design to unpack students' experiences in delivering Pecha Kucha presentations. The Pecha Kucha presentation format was introduced to the Speech Communication subject for two different sophomore classes at a private university in Manila, Philippines during the second semester of the academic year 2016-2017. The participants were 43 pre-intermediate/intermediate level students based on TOEIC scores, aged 18 to 22 , majoring in Bachelor of Science in Accountancy. The textbook used was Speak Well...Get Connected (Custodio, Ambida, \& Nolasco, 2015). Classes convened twice a week for 90 minutes over approximately 4 months or 18 weeks, totaling 54 hours of mixed lecture and laboratory sessions. The Pecha Kuchas were implemented once for both classes during the midterm period as part of class graded recitation.

Class orientation, demonstration, and practice were conducted before the class' Pecha Kucha day. The teacher delivered his own Pecha Kucha to the class in order to demonstrate how it is done. Instructions on how to create Pecha Kuchas using the Microsoft PowerPoint application were provided, and student practiced making their own Pecha Kuchas in the speech laboratory.
Students were encouraged to use their original photos and were advised to cite sources when using images online. As part of class practice, students were asked to create their individual short Pecha Kuchas containing at least five slides (with one image and no more than three words per slide) that were automatically set to transition every 20 seconds and present them in pairs or in triads for feedback, suggestions, and recommendations for improvement. A rubric for Pecha Kucha performance assessment was presented and discussed. The rubric consisted of six categories scoring from one to three on the following criteria: slideshow, speech organization, preparation and presentation of ideas, visual appeal and creativity, topic treatment, and presentation skills. Students wore corporate attire to simulate real-world presentations and were advised to demonstrate effective linguistics (verbal) and paralinguistics (nonverbal, body language, gestures, facial expressions, pacing, pitch, volume, pronunciation, intonation). Presentations were video recorded and uploaded on the class' Facebook group for post-presentation viewing and assessment. Individually, students performed peer evaluation of their classmates' presentation using a presentation rubric. Boud (1995) and Sadler and Good (2006) posit that selfevaluation and self-grading are necessary skills for lifelong learning and are an integral part of the learning process, while Spiller (2012) suggests that peer evaluation can encourage collaborative learning through interchange about what constitutes good work.

Students submitted individual reflections on their Pecha Kucha experience. They described or narrated how they felt before, during, and after the presentation; the preparations they made; their learning from the activity; and the challenges that they encountered as well as their means of addressing them. Students were also asked to respond to a survey created via Survey Monkey and posted on the class' Facebook group. Finally, the teacher asked for volunteers for individual interviews and focus group discussion (FGD) about their Pecha Kucha experience. Forty-three students took the survey and submitted their reflections, 
while 10 students volunteered for individual and group interviews and allowed for their recording. By reflecting on their Pecha Kucha experience, students may enhance their learning (Moon, 1999) and deepen their understanding of the task (Akbari, 2007).

The interview recordings were transcribed, coded, thematized, and analyzed following Guest, McQueen, and Namey's (2012) Thematic Analysis Framework. The survey data was analyzed qualitatively to identify themes and patterns. This data was triangulated with the data from students' reflections, and they were presented in tables and supported with excerpts.

\section{RESULTS AND DISCUSSION Student ratings on the impact of Pecha Kucha presentations}

Items 1 to 7 in Table 1 below explored what students believed to be the impact of performing Pecha Kucha presentations in the speech communication class. The majority of the respondents of Item 1 agreed that Pecha Kucha presentations improved their English speaking and oral presentation skills (69.8\% Strongly Agree and 27.9\% Agree). This finding supports findings from previous studies on improved English speaking and presentation skills (Beyer, Gaze, \& Lazicki, 2012; Christianson \& Payne, 2011; Nguyen, 2015) and improved communication skills (Soto-Caban, Selvi, \& Avila-Medina, 2011). For 6 minutes and 40 seconds, each of the speakers was required to deliver his/her presentation using English - a class presentation rule that had been agreed upon by the class during the Pecha Kucha orientation. This allowed them to use the global language in delivering their topics and exercising selfexpression. Furthermore, students reported that Pecha Kucha presentations developed their presentation skills, which include selecting the topic carefully, organizing and outlining the ideas, selecting appropriate images, creating PowerPoint presentations, rehearsing the presentations, and delivering them in front of audience. As reported by S11 and S23, Pecha Kucha has taught them to consider the linguistic and paralinguistic, as well as the technical and technological aspects of presenting. Similarly, in Item 2, most respondents agreed that Pecha Kucha presentations improved their listening skills (55.8 Strongly Agree and 39.5\% Agree). By carefully listening to over 40 Pecha Kucha presentations of their classmates using the Pecha Kucha presentation rubric, students did not only improve their English listening skills, they also learned valuable ideas from various topics in the presentations.

For Item 3, the majority of the students agreed that preparing for their Pecha Kucha presentations encouraged them to read more about their topics (41.9\% Strongly Agree and 41.9\% Agree), while $16.3 \%$ disagreed, which contradicted the researcher's expectation that students would do a lot of reading and research to create informative Pecha Kuchas. Nguyen (2015) reported a similar finding and attributed it to students' limited exposure to Pecha Kucha, which happened only once during the semester.

Table 1. Results of the questionnaire

\begin{tabular}{|c|c|c|c|c|c|}
\hline Pecha Kucha Presentations... & $\begin{array}{l}\text { Strongly } \\
\text { agree }\end{array}$ & Agree & Undecided & Disagree & $\begin{array}{l}\text { Strongly } \\
\text { disagree }\end{array}$ \\
\hline $\begin{array}{l}\text { 1. improved my English } \\
\text { speaking and presentation } \\
\text { skills. }\end{array}$ & $\begin{array}{c}30 \\
(69.8 \%)\end{array}$ & $\begin{array}{c}12 \\
(27.9 \%)\end{array}$ & $\begin{array}{c}1 \\
(2.3 \%)\end{array}$ & $\begin{array}{c}0 \\
(0 \%)\end{array}$ & $\begin{array}{c}0 \\
(0 \%)\end{array}$ \\
\hline 2. improved my listening skills. & $\begin{array}{c}24 \\
(55.8 \%)\end{array}$ & $\begin{array}{c}17 \\
(39.5 \%)\end{array}$ & $\begin{array}{c}0 \\
(0 \%)\end{array}$ & $\begin{array}{c}2 \\
(4.7 \%)\end{array}$ & $\begin{array}{c}0 \\
(0 \%)\end{array}$ \\
\hline $\begin{array}{l}\text { 3. encouraged me to read more } \\
\text { about my topic. }\end{array}$ & $\begin{array}{c}18 \\
(41.9 \%)\end{array}$ & $\begin{array}{c}18 \\
(41.9 \%)\end{array}$ & $\begin{array}{c}7 \\
(16.3 \%)\end{array}$ & $\begin{array}{c}0 \\
(0 \%)\end{array}$ & $\begin{array}{c}0 \\
(0 \%)\end{array}$ \\
\hline $\begin{array}{l}\text { 4. developed my self- } \\
\text { confidence. }\end{array}$ & $\begin{array}{c}36 \\
(83.7 \%)\end{array}$ & $\begin{array}{c}6 \\
(14.0 \%)\end{array}$ & $\begin{array}{c}1 \\
(2.3 \%)\end{array}$ & $\begin{array}{c}0 \\
(0 \%)\end{array}$ & $\begin{array}{c}0 \\
(0 \%)\end{array}$ \\
\hline $\begin{array}{l}\text { 5. improved my non-verbal } \\
\text { communication skills. }\end{array}$ & $\begin{array}{c}27 \\
(62.8 \%)\end{array}$ & $\begin{array}{c}15 \\
(34.9 \%)\end{array}$ & $\begin{array}{c}1 \\
(2.3 \%)\end{array}$ & $\begin{array}{c}0 \\
(0 \%)\end{array}$ & $\begin{array}{c}0 \\
(0 \%)\end{array}$ \\
\hline 6. encouraged cooperative & 29 & 12 & 2 & 0 & 0 \\
\hline
\end{tabular}


Romualdo A. Mabuan

Developing ESL/EFL learners' public speaking skills through Pecha Kucha presentations

\begin{tabular}{lccccc}
\hline learning. & $(67.4 \%)$ & $(27.9 \%)$ & $(4.7 \%)$ & $(0 \%)$ & $(0 \%)$ \\
7. provided a fun learning & 37 & 6 & 0 & 0 & 0 \\
environment. & $(86.0 \%)$ & $(14.0 \%)$ & $(0 \%)$ & $(0 \%)$ & $(0 \%)$ \\
\hline
\end{tabular}

Responses to Item 4 show that delivering Pecha Kucha presentations developed students' confidence in delivering English oral presentations before an audience. This finding corroborates with the findings of previous studies suggesting that Pecha Kuchas can "develop presenters' sense of confidence in their ability" (Christianson \& Payne, 2011, p. 8 ) and build their "speaking confidence and fluency" (Nguyen, 2015, p. 6). Similarly, in Item 5, most respondents agreed that Pecha Kucha presentations improved their nonverbal communication skills (62.8 Strongly Agree and 34.9\% Agree). Series of Pecha Kucha preparations allowed students to practice applying effective body language skills (posture, facial expressions, body movements, and hand gestures) and linguistic skills (correct pronunciation, intonation, volume, and voice projection). However, $2.3 \%$ was undecided, which may be from students who were shy and diffident to use non-verbal skills during their presentations.

Data for Item 6 shows that majority of the students (67.4\% Strongly Agree and 27.9\% Agree) believed that Pecha Kucha presentations encouraged cooperative learning, which may be attributed to peer teaching and peer assisting in the preparation and practice of their Pecha Kuchas. However, 4.7\% ( $n=2)$ was "undecided" about this, which may have come from shy and/or reluctant students (Nguyen, 2015, p. 139) who preferred to prepare and practice their Pecha Kuchas by themselves. The researchers also observed that low English proficiency students tended to do the practice task on their own, avoiding feedback or criticism from their peers. They only participated in the group during the final presentation. These findings are supported by the following students' avowals.

Table 2. Students' avowals showing the impact of Pecha Kucha presentations

\begin{tabular}{|c|c|}
\hline $\begin{array}{l}\text { Pecha Kucha } \\
\text { presentations... }\end{array}$ & $\begin{array}{l}\text { Interview transcripts and students' reflections showing students' perceptions } \\
\text { on the benefits of Pecha Kucha }\end{array}$ \\
\hline $\begin{array}{l}\text { improve English speaking } \\
\text { and oral presentation skills }\end{array}$ & $\begin{array}{l}\text { It taught me how to present well like preparing for my topic, designing my PPT } \\
\text { and delivering it well to my audience. (S34-F-18) } \\
\text { I believe that it's a very good way to improve my English speaking skill because I } \\
\text { had to speak in English all the time during my presentation. (S20-M-19) }\end{array}$ \\
\hline improve listening skills & $\begin{array}{l}\text { I was able to listen to over } 40 \text { Pecha Kucha presentations of my classmates and I } \\
\text { think that it improved my English listening skill because I needed to do peer } \\
\text { evaluation using our Pecha Kucha presentation rubric. I also learned a lot about } \\
\text { them and their experiences. (SI-M-20) }\end{array}$ \\
\hline encourage reading & $\begin{array}{l}\text { Before presenting my Pecha Kucha, I researched about my topic and read a lot of } \\
\text { materials online and at our library so that I could present my topic well. (S36-F- } \\
\text { 18) }\end{array}$ \\
\hline develop self-confidence & $\begin{array}{l}\text { Pecha Kucha helped me build my self-esteem and self-confidence to stand in front } \\
\text { and express my ideas about my topic. (S11-M-18) } \\
\text { At first I was so nervous and scared to stand in front of my classmates because it } \\
\text { was my first time to do a presentation, but I'm happy that I made it successfully. It } \\
\text { was very memorable for me...one of the best things in my college life so far. (S5- } \\
\text { F-18) }\end{array}$ \\
\hline $\begin{array}{l}\text { improve non-verbal } \\
\text { communication skills }\end{array}$ & $\begin{array}{l}\text { During my Pecha Kucha, I applied what sir told us to project a confident and } \\
\text { correct posture, use appropriate and effective hand gestures, and engage eye } \\
\text { contact with the audience. (S38-M-19) }\end{array}$ \\
\hline $\begin{array}{l}\text { encourage cooperative } \\
\text { learning }\end{array}$ & $\begin{array}{l}\text { Another thing I really like about our Pecha Kucha is that when we were required } \\
\text { by sir to do peer evaluation with the rubric provided. After my Pecha Kucha } \\
\text { presentation, I received immediate feedback from three of my classmates showing } \\
\text { my strengths and my areas for improvement. This made me happy because I felt } \\
\text { that they care for me and they want me to be at my best. (S43-M-22) }\end{array}$ \\
\hline
\end{tabular}


provide a fun learning environment
Presenting a Pecha Kucha and watching my classmates present their own are fun and enjoyable. Of course, I was nervous when it was my turn to present, but after a while, I managed to smile and just enjoyed the moment. It was also very entertaining and at the same very informative to watch my classmates' presentations because I learned new things and I discovered the other side of them. I strongly recommend Pecha Kucha for future speech students. (S14-F-21)
Students' attitudes towards the use of Pecha Kucha in the speech class

An open-ended question was asked to the students to provide their overall description about their Pecha Kucha experience in the class. Generally, students showed positive views and attitudes towards Pecha Kuchas, as they described their Pecha Kucha experience as 'amazing', 'awesome', 'remarkable', 'exciting', 'fun', etc. Some respondents such as $\mathrm{S} 12$ and $\mathrm{S} 33$ reported that it was "an amazing experience" to present their topics and share their ideas with the class, which was affirmed by S26 and S40 who shared that it has been an "awesome" and "unforgettable" moment of their college life. Table 3 lists all of the students' description of their Pecha Kucha presentation experience.

Table 3. Students' attitudes towards the use of Pecha Kucha in the class

\begin{tabular}{lcc}
\hline Students' attitudes towards Pecha Kucha & Responses & \% \\
\hline amazing & 8 & 18.60 \\
awesome & 6 & 13.95 \\
challenging & 3 & 6.98 \\
remarkable & 3 & 6.98 \\
unforgettable & 3 & 6.98 \\
exciting & 2 & 4.65 \\
fun & 2 & 4.65 \\
wonderful & 2 & 4.65 \\
engaging & 1 & 2.33 \\
extraordinary & 1 & 2.33 \\
extreme & 1 & 2.33 \\
fantastic & 1 & 2.33 \\
happy & 1 & 2.33 \\
interesting & 1 & 2.33 \\
marvelous & 1 & 2.33 \\
metamorphic & 1 & 2.33 \\
refreshing & 1 & 2.33 \\
satisfying & 1 & 2.33 \\
stunning & 1 & 2.33 \\
supercalifragilisticexpialidocious & 1 & 2.33 \\
supreme & 1 & 2.33 \\
thankful & 1 & 2.33 \\
Total & 43 & 100 \\
\hline
\end{tabular}

However, as with other educational endeavors, Pecha Kucha presentations have limitations that may implicate its applicability and acceptability in the academic English classroom setting. Seventeen students in this study pointed to some disadvantages of using Pecha Kucha based on their experience in the class. Eight of them (47.06\%) reported that their major concern with the Pecha Kucha format was the twenty-second-per-slide time 
limit, which was 'very strict', 'limiting', and 'unrealistic' because it prevents them to discuss the topic deeply considering that not all of the ideas are of equal value or importance. Other students' concerns with the use of Pecha Kucha include difficulty in topic selection $\quad(\mathrm{n}=5,29.41 \%)$ as it was challenging to think and decide on a presentation topic that is interesting and engaging; PowerPoint application issues $(n=3$, $17.65 \%$ ) as auto-run and other set-ups sometimes did not work properly; and difficulty in image selection $(n=1,5.88 \%)$ as it was time-consuming to select images or photos that will complement with the presenter's ideas. This finding echoes Christianson and Payne (2011) observation that there are "some trade-offs between the benefits of a fixed format and the drawbacks" of Pecha Kuchas. These findings have important implications for future functions and adaptations of Pecha Kuchas in the ESL public speaking classroom and in other relatable contexts elsewhere.

\section{Pedagogical implications}

In the recent past, technology integration into the classroom was considered only as an option; now, it is becoming a sine qua non in the modern classroom (Rabah, 2015) for optimized delivery of the curriculum.

Technology can now be utilized to "substitute, augment, modify, and redefine" (Puentedura, 2014) classroom practices to "enhance and transform" students' learning experiences. The changing nature and needs of the $21^{\text {st }}$ century learner coupled with the challenging demands of an increasingly competitive knowledgebased society implicates a reconfiguration in our pedagogical practices if we are to stay relevant, responsive and meaningful in the context of $21^{\text {st }}$ century education. While some educators and practitioners may be skeptical about the educational value of integrating technology into the classroom, the author argues that it can be one of the feasible and effective means to engage the modern learners - the 'digital natives' (Prensky, 2001) and the 'digital residents' (Booth, 2009) - and address their learning styles in the context of today's digital era. As the industry increases its demands for skilled and well-rounded graduates, our pedagogical practices must be conscientiously and carefully designed and implemented to respond and relate to the call of the times. Teachers can enhance the learning experience of their students by designing and delivering lessons and enriching them with the right choice of technology that helps achieve the target educational outcomes. As Koehler and Mishra (2009) recommended - teachers need to go beyond the "functional fixedness" of technology, and instead need to creatively repurpose it to make it pedagogically viable.

\section{CONCLUSION}

This study investigated students' perceptions and attitudes towards the use of Pecha Kucha presentations in an ESL public speaking class in a private university setting in urban Manila, the Philippines. The results revealed that the students generally view the use Pecha Kucha positively because it can build their confidence in oral presentations, practice their English speaking skills, and develop other English macro skills (i.e., listening, reading, and writing). These findings corroborate with the results of previous studies (Al-Issa \& Al-Qubtan, 2010; Christianson \& Payne, 2011; Beyer, Gaze, \& Lazicki, 2012; Smith, 2013; Ciarrocca, 2015; Nguyen, 2015) that delineate the pedagogical viability of utilizing Pecha Kucha presentations in a classroom context. Although beneficial to the students, teachers should consider the appropriacy and applicability of the Pecha Kucha format in the classroom (Smith, 2013) and some of its drawbacks that may affect students' performance such as time limitations, amount of practice and preparation, topic and image selection, and PowerPoint application settings. Careful class design, implementation, and evaluation are of utmost significance in the success of this technology integration.

Finally, it is important to note some limitations of this study. First, this study was implemented with two ESL public speaking classes among sophomore students in only one semester at one private university in an urban setting. Hence, the results of the study may 
limit their external validity to other contexts, populations, and settings. Second, students presented their Pecha Kuchas only once in the middle of the semester; thus, it may have limited their preparation, readiness, and confidence in delivering oral presentations. Lastly, although Filipino students use English as a second language, asking them to write their reflections and respond to the survey in English may have put some low proficiency students at a disadvantage, which may have caused limitations in eliciting their viewpoints on the use of Pecha Kuchas in the class.

Future studies may explore other subject areas with different sets of learners, levels, and curricula, may employ Pecha Kuchas in the beginning, middle and end of the class term in order to determine its effectiveness in students' performances across time, and may consider providing students options to write their reflections and respond to survey questions using the lingua franca in order to explore deeply their insights on their Pecha Kucha experience. Finally, to establish validity and reliability of the current findings with quantitative data, McCroskey's (1984) Personal Report of Public Speaking Anxiety (PRPSA) may be administered to the students before and after their Pecha Kucha presentations.

\section{REFERENCES}

Akbari, R. (2007). Reflections on reflection: A critical appraisal of reflective practices in L2 teacher education. Systems, 35(2), 192-207.

Al-Issa, A. S., \& Al-Qubtan, R. (2010). Taking the floor: Oral presentations in EFL classrooms. TESOL Journal, 1(2), 227-246.

Beyer, A. A., Gaze, C., \& Lazicki, J. (2012). Comparing students' evaluations and recalls for student Pecha Kucha and PowerPoint presentations. Journal of Teaching and Learning with Technology, 1(2), 26-42.

Beyer, M. (2011). Improving student presentations: Pecha Kucha and just plain PowerPoint. Teaching of Psychology, 38(2), 122-126.

Booth, C. (2009). Informing innovation: Tracking student interest in emerging library technologies at Ohio university. USA: American Library Association.

Boud, D. (1995). Enhancing learning through selfassessment. London: Kogan Page.

Christianson, M. (2011). 20 questions: Can PechaKucha 20x20 help students improve presentation skills? Mark's Learning Blog. Retrieved from http://markchristianson.blogspot.jp/2011/08/20questions-can-pecha-kucha-20x20-help.html.

Ciarrocca, R. (2015). Fostering public speaking through Pecha Kucha in the high school English classroom. Studies in Teaching Research Digest, $1,13-18$

Custodio, E., Ambida, R., \& Nolasco, M. F. (2015). Speak well, get connected. Malabon: Mutya Publishing House.

Horwitz, E. K., Horwitz, M. B., \& Cope, J. (1986). Foreign language classroom anxiety. Modern Language Journal, 70, 125-132.

Klentzin, J., et al. (2010). Pecha Kucha: Using lightening talk in university instruction. Reference Services Review, 38(1).

Koehler, M. J., \& Mishra, P. (2009). What is technological pedagogical content knowledge? Contemporary Issues in Technology and Teacher Education (CITE Journal), 9(1), 60-70.

Lader, M. H. (1975). The nature and clinical anxiety in modern society. In ed. Spielberger, D. Charles \& I. G. Sarason, Stress and anxiety. New York: John Wiley \& Sons.

McCroskey, J. C. (1984). The communication apprehension perspective. In J. A. Daly \& J. C. McCroskey (Eds.). Avoiding communication: Shyness, reticence, and communication apprehension (13-38). Beverly Hills, CA: Sage Publications, Inc.

Milner, J. O., Milner, L. F. M., \& Mitchell, J. F. (2012). Bridging English (5th ed.). Boston, MA: Pearson.

Moon, J. (1999). Reflection in learning and professional development. London: Kogan Page.

Nguyen, H. (2015). Student perceptions of the use of Pecha Kucha presentations for EFL reading classes. Language in Education in Asia, 6(2), 135149.

Partnership for $21^{\text {st }}$ Century Skills. (2006). A state leader's action guide to $21^{\text {st }}$ century skills: A new vision for education. Tuczon, AZ: Partnership for $21^{\text {st }}$ Century Skills.

Pecha Kucha Global. (2017). Retrieved from http://www.pechakucha.org/global.

Puentedura, R. (2014). Learning, technology, and the SAMR model: Goals, processes, and practice. Retrieved from http://www.hippasus.com/rrpweblog/archives/201 4/06/29/LearningTechnologySAMRModel.pdf.

Rabah, J. (2015). Benefits and challenges of information and communication technologies (ICT) integration in Québec English schools. The Turkish Journal of Educational Technology, 14(2), 24-31.

Sadler, P., \& Good, E. (2006). the impact of self- and peer-grading on student learning. Educational Assessment, 11(1), 1-31.

Smith, K. (2013). Pecha Kucha or creatively crafting chit chat presentations with concision and precision. Compass: Journal of Learning and Teaching, 4(7). 


\section{Romualdo A. Mabuan}

Developing ESL/EFL learners' public speaking skills through Pecha Kucha presentations

Souter, N. (2007). Persuasive presentations: How to get the response you need. New York, USA: Sterling.

Spady, W. G. (1994). Outcome-based education: Critical issues and answers. Arlington,VA: American Association of School Administrators.

Spiller, D. (2012). Assessment matters: Self-assessment and peer assessment. Teaching Development Unit, University of Waikato, New Zealand. Retrieved from_https://kennslumidstod.hi.is/wpcontent/uploads/2016/03/assessment-matters-selfassessment-and-peer-assessment.pdf.

Tomsett, P. M., \& Trott, D. (2014). Multimodal pedagogy in international business education. International Journal of Research in Social Sciences, 4(2), 50-56.

What is Pecha Kucha 20x20. (2017). Retrieved from http://www.pechakucha.org/faq. 